\title{
Implementasi Pengujian Theorema Bayes Pada Studi Kasus Pemilihan Smartphone Android
}

\author{
Didik Kurniawan', Feby Eka Febriansyah² dan Afiizka Amidya ${ }^{3}$ \\ 1,2,3 Jurusan Ilmu Komputer, Fakultas Matematika dan Ilmu Pengetahuan Alam, Universitas Lampung \\ Email :afrskamdya@gmail.com
}

\begin{abstract}
Abstrak
Smartphone is internet-enabled mobile that typically provides Personal Digital Assistant (PDA) functions such as calendar, to-do books, address books, calculators, and notes. Smartphone has a function that resembles a computer. In the future, smartphone technology will surpass desktop computer technology, especially in terms of accessing data from internet. With the rapid progress, it prompts android smartphone manufactures to compete in making products with a variety of types and specifications to provide choices for consumers. Theorem Bayes is a method of classifying data, while the basic concept used is a theorem used in statistics to calculate probability. White-box testing is a test case design method that uses the control structure of procedural design in obtaining test cases. In conclusion, by using the concept of probability to produce a value of relative possibility depends on the value of each probabilities.
\end{abstract}

Keywords: smartphone, android, theorem bayes, white-box testing.

\section{PENDAHULUAN}

Saat ini dengan berkembangnya teknologi informasi dengan pesat baik masalah komunikasi, semakin bertambah pula kebutuhan tentang kemampuan komputer dalam membantu menyelesaikan permasalahan-permasalahan di berbagai bidang. Tidak berbeda dengan negara Indonesia yang perkembangan dari segi teknologi semakin terasa dengan manfaatnya tidak hanya dalam komunikasi saja, dan salah satu teknologi yang sedang banyak digunakan adalah smartphone.

Dalam perkembangannya smartphone kini hadir dengan berbagai merek, dan spesifikasi serta harga yang semakin ramah bagi kantong masyarakat Indonesia. Dengan demikian smartphone saat ini tidak lagi menjadi barang mewah, sehingga kebutuhan dan pemanfaatannya semakin tinggi. Seiring dengan perkembangan ilmu dan teknologi, muncul suatu perkembangan model keputusan yang dilakukan dengan cara mengembangkan hubungan yang terjadi di antara faktor-faktor yang terlibat.

Implemnetasi Theorema Bayes untuk menganalisa kerusakan pada Air Coditioner (AC) Ruangan Pada Android yang dilakukan oleh I Putu Warna Putra pada tahun 2016 dalam Pengimplementasian Metode Theorema Bayes. Selain I Putu Warna Putra ada Linda Wahyuni dan Surya Darma yang melakukan Analisa Ketebalan Tempurung Kelapa menggunakan Theorema Bayes pada tahun 2015.

Untuk hal tersebut yang membuat penulis ingin melakukan sebuah pengujian dengan menggunakan metode Theorema Bayes merupakan suatu metode mengklasifikasikan data, di mana Konsep dasar yang digunakan adalah Teorema Bayes yaitu teorema yang digunakan dalam statistika untuk menghitung suatu peluang. dalam pengimplementasian Theorema Bayes dalam studi Kasus Pemilihan Smartphone.

\section{TINJAUAN PUSTAKA}

\subsection{Ponsel Cerdas}

Perkembangan pasar ponsel cerdas dunia yang begitu pesat akhir-akhir ini, tidak terkecuali dengan Indonesia. Banjir ponsel cerdas dan tablet sudah mulai terasa. Derasnya permintaan pasar terhadap ponsel cerdas ini, khususnya yang menggunakan sistem operasi Android membuat para produsen 


\section{(C) Ilmu Komputer Unila Publishing Network all right reserve}

semakin giat untuk berinovasi dan menggempur pasar ponsel Indonesia dengan berbagai produk. Para produsen ponsel cerdas pun mulai datang dari produsen lokal seperti Polytron dan Axioo. Mereka menyadari betapa besarnya pangsa pasar ponsel cerdas di Indonesia.

Ponsel cerdas di Indonesia sendiri memiliki segmentasi yang secara umum bisa dikelompokkan menjadi 3 kelas berdasarkan level harga dan spesifikasinya, yaitu:

1.Ponsel cerdas kelas atas (high-end)

2.Ponsel cerdas kelas menengah (middle level)

3.Ponsel cerdas kelas bawah (entry level)

\subsection{Theorema Bayes}

Sebuah teori telah ditemukan untuk menentukan ketidakpastian, salah satu diantaranya adalah Probabilitas Bayes (Bayes Probability). Probabilitas menunjukan kemungkinan sesuatu yang akan terjadi atau tidak.

Dimana:

$$
P\left(H_{k} \mid E\right)=\frac{P\left(E \mid H_{k}\right) P\left(H_{k}\right)}{\sum_{k=1}^{n} P\left(E \mid H_{k}\right) P\left(H_{k}\right)} \ldots \ldots \ldots \ldots \ldots \ldots(1)
$$

(Hk|E) :Probabilitas hipotesa Hk jika diberikan evidence E

$\mathrm{P}(\mathrm{E} \mid \mathrm{Hk})$ : Probabilitas munculnya evidence $\mathrm{E}$ jika diketahui hipotesa $\mathrm{Hk}$ benar.

$\mathrm{P}(\mathrm{Hk})$ : Probabilitas hipotesa Hk tanpa memandang evidence apapun

$\mathrm{N} \quad$ : Jumlah Hipotesa yang mungkin

$\mathrm{K} \quad: 1 \ldots \ldots \ldots \ldots . . . \mathrm{k}$

Teorema ini lebih banyak diterapkan pada hal-hal yang berkenaan dengan diagnosis secara statistik yang berhubungan dengan probabilitas serta kemungkinan dari penyakit dan gejala-gejala yang berkaitan[2].

\section{METODE PENELITIAN}

Spesifikasi kebutuhan fungsional dari pengujian ini adalah:

1. Daftar smartphone yang diperoleh dari (www.tabloidpulsa.id)

2. Entry data smartphone dan spesifikasinya

3. Entry data spesifikasi dan bobot setiap spesifikasi smartphone .

4.Entry bobot nilai kriteria smartphone untuk menunjukan prioritas keriteria smartphone yang diharapkan.

Metode penelitian yang dilakukan adalah dengan mengumpulkan studi literatur dengan mempelajari aspek-aspek yang berkaitan langsung dengan penelitian berupa mengumpulkan tipe-tipe smartphone android serta mempelajari mengenai metode theorema bayes. Yang kemudian dilanjutkan pengumpulan data dengan menyebarkan Quisioner terhadap 30 orang responden, untuk mengetahui nilai bobot kriteria, setelah itu dilanjutkan dengan perancangan sistem yang menggunakan UML (Unified Modelling Languange) dengan memodelkan masalah kedalam bentuk diagram seperti Use Case Diagram, Class Diagram, Sequence Diagram, dan Activity Diagram. Setelah semua kebutuhan telah memenuhi kemudian dimulai dengan proses pembuatan sistem yang menggunakan bahasa pemprograman Java berbasis Android Mobile. 
Pengujian Sistem yang menggunakan metode white-box testing merupakan perancangan test case yang menggunakan struktur kontrol dari perancangan prosedural dalam mendapatkan test case.

Pengujian white-box atau white-box testing merupakan metode perancangan test case yang menggunakan struktur kontrol dari perancangan prosedural dalam

mendapatkan test case. Adapun metode yang digunakan dalam pengujian white-box ini adalah metode Basis Path. Dengan menggunakan metode White Box analisis sistem akan memperoleh Test Case yang

1. Menjamin seluruh Independent Path di dalam modul yang dikerjakan sekurangkurangnya sekali;

2. Mengerjakan seluruh keputusan logical;

3. Mengerjakan seluruh loop yang sesuai dengan batasannya;

4. Mengerjakan seluruh struktur data internal yang menjamin validitas;

Dalam pelaksanaannya teknik pelaksanaan pengujian White Box ini mempunyai tiga langkah [3].

1. Flow Graph

Digunakan untuk mengetahui adanya kesalahan dalam alur program. Dapat dilihat pada gambar berikut

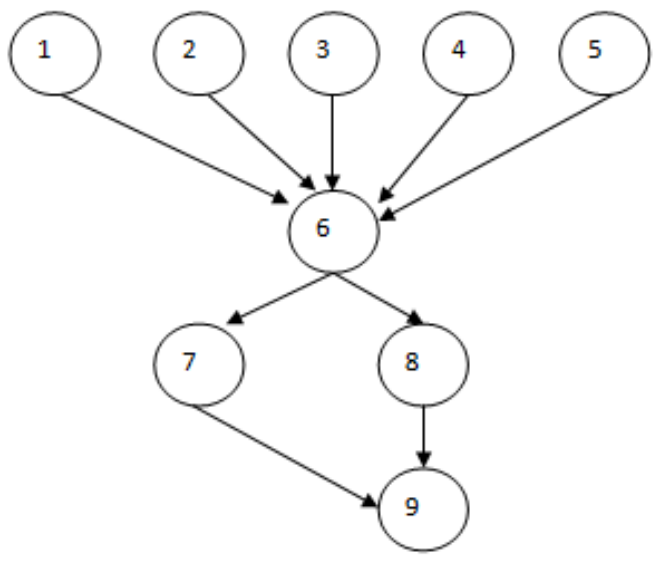

Gambar 2. Flowgraph Algoritma

2. Cylomatic Complexity Flowgraph

Dari flowgraph algoritma yang ditunjukan pada Gambar 2, dapat dihitung Cylomatic Complexity.

Cyclomatic Complexity yaitu metrik perangkat lunak yang menyediakan ukuran kuantitaf dari kekompleksan logikal program dan dapat digunakan untuk mencari jumlah path dalam suatu flowgraph.

a) Flowgraph mempunyai 2 Region

b) $\mathrm{V}(\mathrm{G})=\mathrm{E}-\mathrm{N}+2$

$\mathrm{V}(\mathrm{G})=9-9+2=2$

Keterangan :

$\mathrm{E}=$ Jumlah edge pada flowrgaph

$\mathrm{N}=$ Jumlah node pada flowrgaph

c) $\mathrm{V}(\mathrm{G})=\mathrm{P}+1$

$\mathrm{V}(\mathrm{G})=1+1=2$

Keterangan : 
$\mathrm{P}=$ Jumlah predicate node pada flowrgaph

d) Independent Path

Independen Path yaitu jalur melintasi atau melalui program dimana sekurang-kurangnya terdapat proses perintah yang baru atau kondisi yang baru.

Dari hasil perhitungan cyclomatic complexity terdapat 2 independent path.

- $\quad$ Path $1: 1,2,3,4,5,6,7,9$

- $\quad$ Path $2: 1,2,3,4,5,6,8,9$

\section{KESIMPULAN}

Dari hasil penelitian yang telah dilakukan, diperoleh kesimpulan sebagai berikut.

1. Pengujian dilakukan dengan beberapa data uji dan menghasilnya nilai kemungkinan yang diperlukan .

2. Berdasarkan pengujian dengan metode White-Box Testing dapat disimpulkan bahwa sistem ini dapat berfungsi sesuai dengan kebutuhan dan dapat menampilkan data yang dibutuhkan.

3. Nilai bobot merupakan nilai relatif yang di tentukan berdasarkan jumlah quisioner.

\section{DAFTAR PUSTAKA}

[1] Anggara, G., Pramayu, G., \& Wicaksana, A. (2016, Maret 23). Membangun Sistem Pakar Menggunakan Theorema Bayes untuk Mendiagnosa Penyakit Paru-paru. Seminar Nasional Teknologi Informasi dan Multimedia, Selasa 23 Maret. Jakarta.79-84.

[2] Fowler, Martin. 2004. UML Distilled Panduan Singkat Bahasa pemodelan Objek Standar, Edisi 3. Andi Publishing, Yogyakarta. 